NBER WORKING PAPER SERIES

\title{
PATH DEPENDENCE AND THE ORIGINS OF COTTON TEXTILE MANUFACTURING IN NEW ENGLAND
}

\author{
Joshua L. Rosenbloom \\ Working Paper 9182 \\ http://www.nber.org/papers/w9182 \\ NATIONAL BUREAU OF ECONOMIC RESEARCH \\ 1050 Massachusetts Avenue \\ Cambridge, MA 02138 \\ September 2002
}

I thank Gavin Wright for his comments on an earlier version of this paper and Peter Temin and Doug Irwin for making available to me their data on cotton textile production and tariffs. The views expressed herein are those of the author and not necessarily those of the National Bureau of Economic Research.

(C) 2002 by Joshua L. Rosenbloom. All rights reserved. Short sections of text, not to exceed two paragraphs, may be quoted without explicit permission provided that full credit, including $\mathbb{C}$ notice, is given to the source. 
Path Dependence and the Origins of Cotton Textile Manufacturing in New England Joshua L. Rosenbloom

NBER Working Paper No. 9182

September 2002

JEL No. N6, N4

\begin{abstract}
During the first half of the nineteenth century the United States emerged as a major producer of cotton textiles. This paper argues that the expansion of domestic textile production is best understood as a path-dependent process that was initiated by the protection provided by the Embargo Act of 1807 and the War of 1812. This initial period of protection ended abruptly in 1815 with the conclusion of the war and the resumption of British imports, but the political climate had been irreversibly changed by the temporary expansion of the industry. After 1815 nascent manufacturers sought to protect the investments they had made by lobbying Congress. Their efforts had an important impact on the provisions concerning cotton textiles in the tariff bill of 1816, and during the 1820s manufacturers won increasingly strong protection, culminating in the passage of the "Tariff of Abominations" in 1828.
\end{abstract}

Joshua L. Rosenbloom

Department of Economics

University of Kansas

1300 Sunnyside Avenue

Lawrence, KS 66045

and NBER

jrosenbloom@ku.edu 
At the beginning of the nineteenth century, the United States was a minor contributor to world production of cotton textiles. Yet by mid-century the United States was the world's second largest producer of textiles. ${ }^{1}$ The rapid take-off in American textile production is summarized in Table 1, which shows numbers of spindles in the United States and Britain in the century after 1790. With the growth of textile production, the United States also developed an active community of textile machinery producers who became a source of important innovations in both factory spinning and weaving technologies. In particular, Americans were the leading innovators in the development of ring spinning techniques, while British machinery producers concentrated on advancing mule spinning. During the second half of the nineteenth century American advances in ring spinning made their way back across the Atlantic, as British machinery producers began to borrow from Americans. ${ }^{2}$

The rapid growth of the American textile industry during the nineteenth century was an important component of the broader process of American industrialization. Cotton textile factories were the single largest employer of manufacturing labor and textile machinery producers made important contributions to the production of steam engines, locomotives, and other industrial machinery. The concentration of textile producers in the New England region for most of the nineteenth century magnified their impact on the regional economy. Because of the geographic concentration of textile production, New England industrialized much more rapidly than did the rest of the country. By 1880 , close to 40 percent of New England workers were employed in manufacturing, and of these 37 percent were employed in the production of textiles. In other words, 
approximately one of every six workers in New England was engaged in textile production.

Viewed from the perspective of the early nineteenth century it was not at all obvious that the United States would emerge as an important producer of cotton textiles. Population and markets were small and widely scattered, capital was expensive, and skilled textile workers were in scarce supply. ${ }^{3}$ That the industry would become localized in New England would also have been difficult to predict at this time. Although some accounts have emphasized water power as a potential source of locational advantage, this explanation does not stand up to careful examination. There were in fact many comparable water power sites in the Mid Atlantic region, and in the Piedmont areas further South. ${ }^{4}$ Moreover, according to Albert Bolles, writing toward the end of the nineteenth century, the region's natural endowment was if anything unconducive to textile manufacturing.

The climate was dry and cold, entailing a large expense in warming and steaming the air of the mills...The factories were situated many hundreds of miles away from the cotton growing regions, entailing another large expense...[And] the waterpower of the South was as abundant and cheap too, as that of the North. ${ }^{5}$ While purely locational factors do not help to explain New England's leadership in textile production, a more persuasive case can be made for the role of labor supply conditions. ${ }^{6}$ Nonetheless, labor supply appears to have been more important in allowing the industry to expand after its initial establishment than in influencing entrepreneurial decisions about where to locate factories. ${ }^{7}$ 
In light of the importance of cotton textiles in both national and regional economic development it is important to understand how and why the U.S. industry developed when and where it did. As befits a topic of this importance the history of New England textile production has been documented in considerable detail. ${ }^{8}$ My purpose here is to offer a new interpretation of these facts. In this chapter I argue that the development of the American cotton textile industry, and its localization in New England can best be understood as a path-dependent process in which transitory historical "accidents" altered the course of development producing effects long after the conditions to which they gave rise had disappeared. ${ }^{9}$

Specifically, I argue that the protection provided by the Embargo Act of 1807 and the War of 1812 led to the initial expansion of textile manufacturing in the United States. This transitory period of protection ended abruptly in 1815 with the conclusion of the war and the resumption of British imports. But the political climate had been irreversibly changed by the temporary expansion of textile manufacturing. Nascent manufacturers for the first time sought to influence tariff policy. Their lobbying had an important impact on the provisions concerning cotton textiles in the tariff bill of 1816, and during the $1820 \mathrm{~s}$ manufacturers won increasingly strong protection, culminating in the passage of the "Tariff of Abominations" in 1828. In particular, the 1816 bill incorporated a provision specifying a minimum valuation for textiles that created substantially greater protection for the less expensive and coarser fabric produced by the newly established Boston Manufacturing Company. This protection was important in providing the company the time it needed to perfect the novel system of production — relying on the power loom and vertically integrated production - that it had introduced, and initiating the process of 
technological innovation that led to rapidly falling costs. Although the focus of my account is on the relationship between the temporary episode of protection after 1807 and the development of the power loom, this was not the only channel through which path dependence operated. The impact of the early industry's development on the formation of an industrial labor force, and the creation of a community of engineers and mechanics familiar with the construction and maintenance of textile machinery provided additional sources of irreversibility that helped to promote the growth of the industry once it had been established.

There is, of course, a large literature devoted to the question of whether protective

tariffs were important in the development of the American textile industry. ${ }^{10}$ But most of this literature has focused its attention on the question of whether the higher rates enacted in the 1820 s were essential. Given the limitations of the data, this question is unlikely ever to be resolved to the full satisfaction of all participants, but it is my contention that it was the earlier period of protection that preceded the tariff that was crucial in setting the stage for subsequent growth, and indeed in influencing legislative actions that resulted in protection, whether necessary or not. In the absence of these events, the course of American economic development could well have been substantially different.

\section{The Early Development of the American Textile Industry}

Before 1807 the scarcity of skilled labor and capital in conjunction with small and diffuse markets for yarn and cloth discouraged the growth of textile production in America. Americans were well informed about British innovations in textile technology and there had been a number of successful efforts to recruit British artisans with the 
knowledge to build and operate machinery based on these innovations. Yet, the American industry remained small in size and limited in scope. In 1807, there were still just 8,000 spindles in operation in America, a miniscule figure when set against the millions of spindles in Britain at this time.

The small size of the American industry reflects its competitive disadvantages in this era, not a lack of information about British technology. Knowledge of British innovations in spinning crossed the Atlantic quite rapidly. Within 5 years of Hargreave's 1770 patent on the spinning jenny, for example, two 24 -spindle jennies were in operation in Philadelphia, one having been built for a immigrant weaver, and the other constructed by a local craftsman. ${ }^{11}$ Although the jenny multiplied yarn output, it still relied on skilled labor for its operation, and the shortage of such skilled labor was apparently a significant obstacle to its widespread adoption in the United States. Despite the efforts of various groups throughout the Northeast to promote domestic textile manufacturing, capacity expanded only slowly. By 1790 there were still fewer than 10 textile manufactories in the United States operating less than 2,000 jenny spindles.

Typical of these efforts was the Beverly Cotton Manufactory, which was formed by a group of Massachusetts merchants in 1787. The founders hired an English emigrant weaver, Thomas Somers, to supervise operations, and equipped the company with an Arkwright roller card, four jennies, a twisting mill, a warping mill, and fly shuttle looms. Despite attracting the attention of many visitors, the company was unable to turn a profit even though it was exempted from taxation, and subsidized by the state legislature.

Confronted with continuing losses it shut its doors within a few years. ${ }^{12}$ 
While hand powered jennies offered little advantage to American producers, other British spinning technologies appeared more promising for American circumstances. In particular, Arkwright's waterframe provided a route to powered spinning of strong but coarse cotton yarn that largely dispensed with the need for skilled operatives to tend the machinery. Construction of the machines required specialized knowledge, and mill management similarly required a degree of skill and experience, but the machinery itself could be operated almost entirely by young children. ${ }^{13}$

Because of British prohibitions on the export of textile machinery, and the absence of written documentation describing the design and operation of Arkwright's invention, however, the only way to for prospective American producers to obtain this new technology was to recruit British artisans with the requisite knowledge to reproduce the machines. ${ }^{14}$ By the late 1780 s there were a number of Americans seeking to recruit such skilled British workers. Among them was a pair of Providence, Rhode Island merchants, William Almy and Moses Brown, who were at this time experimenting with a diverse array of manufacturing activities, including operating a stocking frame, spinning wool, and using a fly-shuttle equipped loom to weave cloth. Almy and Brown were also spinning cotton on hand jennies and having it woven on linen warp, and they had purchased several machines based on Arkwright's designs, but had been largely unsuccessful in getting them to work. ${ }^{15}$ In 1789 , however, they obtained the services of Samuel Slater, a British immigrant with direct knowledge of Arkwright's technology. In partnership with Almy and Brown, Slater set about construction of the first water powered spinning mill in the United States. 
In contrast to other textile ventures at this time Almy and Brown's partnership with Slater proved successful enough to warrant a gradual expansion. While continuing his partnership with Almy and Brown, Slater soon established his own spinning factory, and over the next decade and a half small spinning mills proliferated in southern New England, many of them operated by Slater's relatives and associates and closely following the initial model he had laid out. These mills remained small operations and confined their activities to spinning yarn. The initial operations of picking and beating the cotton yarn remained a hand activity performed outside the factory, as did the weaving of yarn into cloth.

Despite the limited success of Almy, Brown and Slater, it is clear that domestic producers faced stiff competition from Britain. Indeed, with the outbreak of war in Europe in 1793, British producers sought to expand their export markets in North America to compensate for the loss of continental outlets for their production. Reflecting these efforts, between 1793 and 1807, British exports to North America grew from $£ 1.6$ million to $£ 10.2$ million, accounting for more than 30 percent of total exports in most years during this period. ${ }^{16}$ While figures for both domestic production and imports are somewhat problematic, Douglas A. Irwin and Peter Temin estimated that total value of cloth produced in New England in 1807 was only about 8 percent of the value of cloth imported from Britain. ${ }^{17}$

The modest growth of American factory production of textiles relied largely on the waterframe. ${ }^{18}$ In contrast, mule spinning, which was much more prominent in Britain, made limited progress in the United States. Like the spinning wheel and jenny (and unlike the waterframe) the mule relied on intermittent spinning in which yarn was 
first drawn out and twisted, and was then spun onto the spindle. Unlike the waterframe, the mule required adult operatives with considerable skill and hand-eye coordination, but it allowed for the production of finer yarns, and made it possible to utilize shorter-staple cottons than were possible with the waterframe. ${ }^{19}$ By 1790 , British factories had nearly 700,000 mule spindles in operation compared to just 310,000 waterframe spindles.

While both numbers continued to grow, the number of mule spindles grew more quickly, reflecting the advantages in the British context of the mule's greater versatility in producing a range of different yarns along with the more abundant supply of skilled mule spinners. $^{20}$

The passage of the Embargo Act, which took effect in December 1807, effectively blocking trade with Europe caused a dramatic shift in the fortunes of domestic manufacturing in the United States. The Embargo created in effect nearly complete protection for domestic producers while substantially contracting export markets for raw cotton and thus lowering the price of this crucial input. Although the longer-run effect of the embargo was to stimulate production, the immediate effect was a sharp reduction in demand for American yarn. Almy and Brown's chief markets were in New England, and the merchants upon whom they relied to distribute yarn were hit hard by the collapse of trade caused by the embargo. Nonetheless, the embargo created new opportunities that soon buoyed production. ${ }^{21}$

The growing population in the trans-Allegheny west had until now been supplied largely with fabrics imported by Philadelphia and Baltimore merchants. Faced with the cessation of these imports, merchants in these Mid-Atlantic cities turned to the New England mills. Prior to the embargo, more than half of Almy and Brown's sales had been 
to merchants in Boston and other northern New England cities. In 1808, however, this share fell to just 17 percent, while Philadelphia and Baltimore together accounted for 44 percent of their sales, up from 24 percent in $1806 .^{22}$

The cessation of trade caused by the Embargo Act, and the subsequent disruptions due to the Non-intercourse Act and the open hostilities with Britain that began in 1812 made domestic production much more profitable than it had previously been. As Figure 1 illustrates, while the prices of cloth rose, the cost of raw cotton was falling after 1808 . The partial resumption of trade after the repeal of the Embargo Act caused cloth prices to fall in 1810 and 1811, but the outbreak of war with Britain in 1812 caused the gap between input and output prices to widen further. In this period, falling raw materials costs in combination with rising product prices suddenly made textile manufacturing a much more attractive opportunity, especially for merchants whose capital was now released from international trade. Figure 2 makes clear just how abrupt the response to the shift in business opportunities was. From 1800 through 1807, just 5 textile manufacturing firms were incorporated in New England and the Mid Atlantic states. In 1809, 18 new companies were incorporated. Another 17 were formed in 1810, and the number of incorporations continued to increase thereafter, reaching a peak of 105 in 1814. The resulting growth in domestic manufactures is also apparent in the industry's consumption of cotton. Between 1800 and 1805, the growth of domestic cloth production had doubled consumption of cotton from 500 to 1,000 bales. In the next five years cotton consumption increased ten-fold, and by 1815 it had grown to 90,000 bales. ${ }^{23}$ Peace and the resumption of British imports brought this period of expansion to an abrupt end, a fact clearly reflected in the sharp drop in factory incorporations after 1814. 


\section{The Origins of the Massachusetts System}

The growth of domestic textile production in the United States after 1807 was based almost entirely on supplying the growing demand for cloth, not yarn. To meet this demand the Slater-style mills of southern New England were obliged to find weavers to convert their factory spun yarn into fabric. They did this through a proliferation of arrangements with individual weavers. But this situation proved highly unsatisfactory for a number of reasons. The supply of weavers in proximity to the spinning mills was quickly exhausted, making it necessary to contract over increasingly long distances. Many of the weavers Slater dealt with, for example, were more than 20 miles away. Moreover, individual weavers proved unreliable, and the quality of their work varied substantially. Almy and Brown expressed their frustration in securing regular deliveries from outworkers in an 1809 letter, observing that "we have several hundred pieces now out weaving... but a hundred looms in families will not weave as much cloth as ten at least constant workmen." The next year they abandoned outwork entirely, setting up a group of hand weavers in their workshop and instructing their superintendent to spin only as much yarn as these weavers could convert into cloth. ${ }^{24}$

The scarcity of hand weavers was thus a significant bottleneck to the growth of the American textile industry. Seeking to overcome this obstacle a number of manufacturers and mechanics sought to develop a power loom. British innovators had been working on developing power looms as well, but the much more abundant supply of skilled hand weavers must have made the need for such an innovation far less pressing. ${ }^{25}$ Among the Americans interested in power weaving was Francis Lowell, a Boston 
merchant. Lowell had spent several years in Scotland, and had made careful observations of British textile technologies during his time abroad. Now he drew on this knowledge to develop plans for a power loom. In 1813, during the wartime boom in domestic textile production, Lowell in combination with a small group of Boston businessmen established the Boston Manufacturing Company, with the goal of spinning and weaving cotton cloth in a single integrated factory. ${ }^{26}$ Working with a skilled mechanic, Paul Moody, he was able to construct a satisfactory loom, and the Boston Manufacturing Company produced its first cloth in 1815 .

In contrast to American borrowing of spinning technology, the development of power weaving proceeded more or less in parallel in the United States and Britain, and Lowell's solution to the problem of power weaving was rather different from British efforts. From the outset, Lowell's goal was to weave a single, uniform product. As Nathan Appleton, one of Lowell's associates in the formation of the Boston Manufacturing Company recalled: "The article first made at Waltham, was precisely the article of which a large portion of the manufacture of this country has continued to consist; a heavy sheeting of No. 14 yarn, 37 inches wide, 44 picks to the inch, and weighing something less than three yards to the pound." This was a plain, coarsely woven, but durable fabric that Lowell intended to compete primarily with the "yard wide goods of India" that had heretofore supplied the country. ${ }^{27}$

By dispensing with the need for flexibility, and concentrating on weaving coarse yarn, Lowell was able to substantially simplify the mechanical problem of building his loom. In particular, because the coarser yarn that Lowell planned to use would be able to withstand relatively greater stresses than finer yarns, he was able to dispense with the 
need for a variable speed batten and the complex gearing that that implied. There is little evidence to document the evolution of Lowell's thinking at this time, so it is difficult to say if he was remarkably prescient in adapting the Boston Manufacturing Company's production process to America conditions, or if he was simply lucky. But in either event the system that emerged was remarkably well suited to the factor proportions and product markets that confronted American producers at this time. Using coarse yarn spun on waterframes to weave a coarse but durable fabric, Lowell was able to substitute higher quality raw materials and special purpose machinery for relatively scarce skilled labor, while meeting a growing domestic market. $^{28}$

Developing a power loom was essential to overcoming the shortage of hand weavers in the United States, but the decision of Lowell and his associates to embed the use of the loom in an integrated textile factory was arguably as important in terms of its influence on the industry's subsequent development. From the outset, Lowell envisioned the Boston Manufacturing Company as encompassing the entire range of production activities involved in converting raw cotton into cloth. In particular this meant that spinning and weaving operations could be closely matched to each other, ensuring that yarn suitable for the power looms was produced in the appropriate quantity, and that there would be a use for all of the yarn that was spun by the factory. This close integration, in conjunction with the decision to produce a single uniform type of fabric also reduced the need for flexibility in production.

Although the technologies adopted by the Boston Manufacturing Company did not require craft skills, they nonetheless placed substantial demands on existing sources of labor supply. The scale of the company's operations required a much larger labor 
force than existing spinning mills had needed, and the physical demands of operating the equipment meant that the bulk of this labor had to be performed by adults. An adequate supply of labor was not to be found at the factory site. To meet its labor needs the company was obliged to innovate by recruiting young women from rural areas of New England and providing suitable housing for them near the factory. ${ }^{29}$ That there was a large pool of potential labor in the countryside to be recruited facilitated the industry's subsequent expansion, but there is little indication that this realization had much impact on the company's initial choice of location. ${ }^{30}$

While Lowell and his associates focused on mechanizing and speeding up the production of a small range of fabrics by substituting special purpose machinery for skilled labor, British inventors devoted considerable attention to the development of machinery that could be adapted to produce a broad range of different yarns and fabrics. In doing so, the machinery they devised continued to rely much more heavily on the more abundant supplies of skilled mule spinners available in Britain. Such a strategy was essential in the vertically disintegrated British industry, where spinning mills had to be able to adapt to the shifting demands of weavers. It also reflected the larger market for high quality products that British manufacturers supplied. ${ }^{31}$ Britain's continued reliance on mule spinning reinforced the divergence of the two national systems because the primary route into the ranks of skilled mule spinners was through informal apprenticeship as a piecer. ${ }^{32}$ Thus an important by-product of reliance on mules was the production of the next generation of mule spinners.

Beyond reducing demand for skilled mule spinners and hand weavers, the Boston Manufacturing Company's decision to integrate production served to focus innovation on 
bottlenecks in the production process. Realizing the benefits of the new power looms, for example, required improvements in the process of warping and dressing. After the introduction of the power loom, Moody turned his attention to improving existing techniques for winding and dressing the warp yarns for power looms. By altering the position of the warping beams and adding drying fans he was able to speed the process of dressing the yarn, while the introduction of stop action devices that would detect breaks in the yarn allowed warping to be carried out more rapidly. Because of the stresses it placed on the yarn the Waltham loom also required yarns with a relatively high twist. Imparting this twist meant that spindles had to turn more slowly, and increased the number of spindles necessary to supply each loom. This trade-off encouraged American innovators to search for ways to increase the speed at which yarn could be spun. At the same time that integration focused attention on bottlenecks slowing production, it also created opportunities for cost savings. A good example of this is provided by Moody's development of a filling frame that used bobbins that could be used in powered looms, thus avoiding a separate step to wind the yarn onto the bobbins. ${ }^{33}$

The Boston Manufacturing Company commenced production in January 1815, and by 1816 the initial plant, equipped with 2,000 spindles, was in full operation. By early 1818 a second mill was under construction. During these early years Moody continued to refine existing machinery, and develop new equipment. By about 1820 Moody had completed the basic set of machinery on which the Waltham system rested, but the rapid pace of advance in total factor productivity throughout the $1820 \mathrm{~s}$ and $1830 \mathrm{~s}$ suggests that learning-by-doing continued to create substantial opportunities for incremental improvement in the production process. ${ }^{34}$ By 1820 the company had 
exhausted the available water power sources in Waltham, and many of the original investors along with a few new ones began to explore new sites for future expansion, settling eventually on what would become the town of Lowell. In December 1821 this group established the Merrimack Company to construct a factory at this site. Over the next decade the same close knit group of investors founded additional companies as demand for their product continued to grow rapidly. ${ }^{35}$

While the textile industry in Massachusetts grew through the multiplication of factories based on the underlying technology developed by Lowell and Moody at the Boston Manufacturing Company, textile firms in Rhode Island followed a different path of development. For a number of years, these firms continued to rely on hand weaving to produce finer and more complex fabrics, such as checks and plaids, which could not be produced on power looms. But competition from imported cloth imposed significant pressures on these companies, and most went out of business. The resulting decline in demand for hand weavers helped to reduce hand weaving rates, however, making it possible for the survivors to hold out for quite a while. Slater, for example, did not abandon hand weaving until 1827 . Thus, there was a gradual convergence toward integrated production and power looms throughout New England, but the route followed by the Rhode Island producers was rather different from their neighbors to the North. ${ }^{36}$

In contrast to the technological convergence of the industry in New England, producers in Philadelphia continued to rely more on hand weaving, producing finer and more varied goods, and seeking to adjust production to changes in market demand. ${ }^{37}$ The Philadelphia producers struggled, however, in the face of import competition, and they remained a relatively small part of the American industry. In 1831, Pennsylvania 
produced just 10 percent of the nation's cloth, while New England accounted for 71 percent. $^{38}$

\section{Tariff Protection and Path Dependence}

The protection from foreign competition afforded the American textile industry after 1807 was instrumental in the rapid expansion of capacity, and encouraged the emergence of a uniquely American set of production technologies promoted by Francis Lowell and embodied in the Boston Manufacturing Company. The argument for path dependence hinges, however, on making the case that this initial "historical accident" altered the course of the industry's subsequent development. One important and irreversible consequence of the industry's growth in this period was a change in the political environment in which subsequent discussions of tariff policy took place. In this context Congress adopted in 1816 a tariff bill that provided an important degree of protection for the industry, preventing a return to the pre-war status quo and providing Lowell and Moody with the opportunity to work out the details of the Boston Manufacturing Company's production process.

Following the ratification of the Treaty of Ghent in February 1815 the country was flooded with imports. During the year ending September 30, 1814 total imports were valued at just $\$ 12.97$ million. In the following year this figure increased almost ninefold, to $\$ 113$ million. In 1816 the value of imports increased again, reaching \$147 million. ${ }^{39}$ Among these imports were large quantities of yarn and cloth offered at low prices. Confronted with this competition, America producers substantially scaled back production. Douglass A. Irwin and Peter Temin estimate that the value of imported 
British cloth rose from zero in 1814 to $\$ 21$ million in 1815 . Because of the long voyages involved, Indian and Chinese imports did not increase until 1816, but then their value shot up as well. Under pressure from these imports, the value of cloth production in New England fell from $\$ 47,160$ in 1815 to just $\$ 16,355$ in $1816^{40}$

The effect of renewed competition was devastating for American textile producers. In June 1816, Nathan Appleton accompanied Lowell on a tour of a number of Rhode Island mills, finding production at a standstill:

We proceeded to Pawtucket. We called on Mr. Wilkinson, the maker of machinery. He took us into his establishment — a large one; all was silent, not a wheel in motion, not a man to be seen. He informed us that there was not a spindle running in Pawtucket, except a few in Slater's old mill, making yarns. All was dead and still...We saw several manufacturers; they were all sad and despairing. ${ }^{41}$

Without additional protection it appears that conditions would have returned to something like the situation that prevailed before 1807 . Recognizing this, many of the new manufacturers turned to Congress in hopes of rescuing their investments.

The temporary increase in duties passed at the outset of the War of 1812 was slated to end one year after conclusion of the peace treaty. Consequently early in 1816 Congress took up the question of establishing new duties. Reporting on the subject, the Committee on Commerce and Manufactures explicitly noted the difficulties of cotton manufacturers, and the numerous petitions that had been received from them advocating greater tariff protection. Citing the perilous condition of these manufacturers, the committee went on to note that passage of a protective tariff would put the manufacturers 
“...again into operation with increased powers; but should it be withheld they will be prostrated....A capital of near sixty millions of dollars will become inactive, the greater part of which will be a dead loss to the manufacturers." ${ }^{42}$

Textile manufacturers efforts to influence tariff legislation extended beyond petitioning Congress for support. It is apparent from the records of the subsequent debate in Congress that for the first time a number of manufacturers were present in Washington during discussion of the tariff bill, and that members of Congress consulted with them to ascertain the effects of potential legislation. ${ }^{43}$ Prominent among those manufacturers seeking to influence the tariff was Francis Lowell, who was instrumental in shaping an important piece of the resulting legislation: the provision in the bill that established a minimum valuation for cotton cloth imports of 25 cents per square yard. As a result of this provision cloth valued at its place of export at less than 25 cents per yard was taxed as if its value was 25 cents. Such a provision fell heavily on the Indian textiles that Lowell envisioned as the primary competition for the Boston Manufacturing Company's product. Since these fabrics cost only about 8 or 9 cents per yard in India, the minimum effectively increased their price by over 80 percent. ${ }^{44}$

Lowell's position was at odds with most of the other producers, and the more moderate position that he adopted on the tariff rate won the support of a number of key southern representatives. Describing the situation, Appleton wrote: "The Rhode Island manufacturers were clamorous for a very high specific duty," but Mr. Lowell's "views on the tariff were much more moderate, and he finally brought Mr. Lowndes and Mr. Calhoun [both of South Carolina], to support the minimum....45 By focusing on the minimum clause rather than a high overall rate, Lowell had found a way to circumvent 
important sectional conflicts on trade, and win the backing necessary to gain protection that he believed his company needed. Because Indian textiles did not use American cotton, it was possible for at least some influential southern Congressmen to support the minimum clause, which effectively excluded Asian cloth, while continuing their opposition to high overall tariff rates, which would threaten the British manufacturers who were the main consumers of America cotton. ${ }^{46}$

The importance of Lowell's strategy, and the effect of his effort to win southern support for the minimum is apparent in the two key votes on the tariff bill, which are compared in Table 2. In the first vote, the House by a large majority voted to reduce the proposed tariff on textiles from 30 percent in the first 2 years to 25 percent for two years, followed by a 20 percent rate in subsequent years. As Table 2 makes clear, the majority of support for the higher rate came from the Mid Atlantic and Midwest. Votes from the New England delegates - reflecting the region's strong mercantile interests—were nearly 2-to-1 for the lower rate, Rhode Island's representatives did vote in favor of the higher rate. As expected, the South was strongly against higher tariffs, voting nearly 5-to-1 to lower the rate. A few days later the House turned to the question of the minimum, rejecting a proposal to eliminate this provision. Once again, the Mid Atlantic and Midwestern representatives voted strongly in favor of protection. Although representatives from the southern states still voted against the tariff bill, the margin narrowed considerably, with delegates from South Carolina—one of the major cotton growing states - now voting 6-to-3 in favor of the minimum. In New England, as well, the pattern of voting shifted notably. In contrast to the earlier vote, New England legislators voted strongly in favor of the minimum. Interestingly, a large number of the 
representatives from Massachusetts ducked this vote and were not recorded, possibly reflecting an effort on their part to avoid offending either the state's mercantile and nascent manufacturing interests.

By advocating the minimum provision Lowell had succeeded in finding a workable political compromise that provided the Boston Manufacturing Company with considerable protection from its chief competition: low-priced Indian textiles. The minimum was in effect essentially a prohibitory rate. As the Boston merchant Henry Lee wrote after passage of the minimum: "We have given up the Calcutta trade, except for raw cotton, Manufactures will not do-The Duty on coarse Cloths under new Tariff is from 60 to $70 \% \ldots{ }^{47}$ In the wake of its adoption the value of imports from India fell by nearly two-thirds between 1816 and $1817^{48}$

The tariff of 1816 provided some protection for other producers as well, reducing the flow of British imports. But the postwar slump, foreign competition and the collapse of western currencies greatly strained many of the more traditional textile firms in Rhode Island and around Philadelphia, whose products competed more directly with those of British manufacturers. Many went out of business, and others substantially scaled back production. One of the clearest signs of contraction is the declining demand for hand weavers, who saw piece rates fall from a third to a half between 1816 and 1820 as they were squeezed between the lower cost of machine woven plain cloth and the low prices of imported fancy goods from Britain. ${ }^{49}$

The continued depression of traditional textile manufacturers in Philadelphia was clearly captured in data collected for the census of 1820. At the firm of Craige, Holmes $\&$ Co., which had begun production in 1809 , the number of outwork weavers fell from a 
peak of 300 during the war to only 150 by 1820 . Other manufacturers had also contracted production substantially. Table 3 documents the dramatic decline in employment. Overall textile employment in Philadelphia fell by almost 85 percent from its peak in 1816 to its trough in 1819 , with yarn production and cotton weaving being hit much harder than wool or other products such as hosiery and rugs. Even by 1820 , as employment had begun to bounce back, employment was still only about 30 percent of its 1816 level. $^{50}$

In contrast to the depressed conditions of Rhode Island and Philadelphia textile firms, the Boston Manufacturing Company was expanding rapidly at this time. Sales increased from $\$ 412$ in 1815 to $\$ 23,628$ in 1816 , and had reached $\$ 260,658$ by 1820 despite declining cloth prices. ${ }^{51}$

Was the protection provided by the tariff of 1816 essential to the Boston Manufacturing Company's success in this period? The evidence on this point is circumstantial, but suggestive. First, it is evident that in 1816 Lowell believed that this protection was vital. His presence in Washington during the Congressional discussion of the tariff, and the efforts he devoted to insuring the passage of the minimum clause provide some indication of the importance he placed on this measure. But it is also important to keep the chronology of events in mind. The Boston Manufacturing Company had only begun production in early 1815 , just as the Peace Treaty was concluded, and the volume of its production and sales in that year was miniscule. Paul Moody had worked out solutions to a number of the technological challenges of integrated production by 1816 , but it was not until 1820 that he had developed versions of all of the machinery that would comprise the Waltham system. And the sustained 
improvements in productivity over the next two decades point to the considerable room for additional improvement that remained at this point. As a result it is easy to imagine that there must have been considerable uncertainty about the company's prospects at this time. Supporting this view Figure 3 compares the prices of Waltham cloth, with that of Russian Brown sheeting. In 1815, Waltham produced cloth was nearly 20 percent higher in price than its competitor. But by 1819 , this gap in prices had been eliminated and thereafter prices of the two fabrics followed a comparable downward trend. In view of these facts, there is good reason to believe that without the minimum the Boston Manufacturing Company's investors would have been reluctant to make the additional investments in perfecting the company's technology and expanding its capacity. And without these investments the American industry would have developed much more slowly, if at all. ${ }^{52}$

During the 1820s the effective level of tariff protection for the American industry increased substantially. Even without additional Congressional action, falling textile prices driven by sustained technological improvements in efficiency would have increased the range of fabrics to which the minimum valuation applied. But in 1824 Congress raised the minimum valuation to 30 cents per yard, and in 1828 increased it again to 35 cents. By 1830, Douglas Irwin and Peter Temin have calculated that the average ad valorem tariff on British textile imports amounted to over 40 percent. With falling prices, the effective tariff continued to increase, reaching a peak of nearly 50 percent in the early 1840 s before being dramatically scaled back in the tariff bill of $1846 .{ }^{53}$ There is, however, little evidence that the Massachusetts textile firms viewed this additional protection as necessary for their survival, and they did not lobby for these 
increases. Increased protection, however, may have been more important in sustaining the smaller and less mechanized branches of the industry in Philadelphia and Rhode Island.

While the additional protections enacted after 1816 may have been unnecessary from the perspective of the Boston Manufacturing Company, some level of tariff protection appears to have been important for an extended period of time. Determining when the American industry could have competed without protection is controversial and unlikely to be completely resolved given the limitations of the data. F.W. Taussig contended that by 1833 the period of the American industry's infancy had come to an end, and that tariff protection was no longer necessary. ${ }^{54}$ More recently, however, Mark Bils and C. Knick Harley have argued that had tariffs been eliminated at this time a large part of the American industry would have been driven from the market by competition from British imports. ${ }^{55}$ Drawing on comparisons of the prices of similar British and American products, which are available from the early 1840s, Harley concluded that throughout the 1840s and 1850s American prices would have been above the prices of British cloth plus the costs of trans-Atlantic shipping. While the pre-1846 tariffs were so high as to be redundant, Harley showed that even after 1846, the more limited tariffs still in effect were enough to offset British cost advantages. This conclusion is supported by the fact that American cloth was largely uncompetitive with British cloth in third markets, such as Canada, where the two products competed on an equal footing. Recently, Douglas A. Irwin and Peter Temin have challenged Harley's interpretation. based on econometric analysis of the relationship between the relative price of imported cloth and domestic cloth production. ${ }^{56}$ Irwin and Temin found that domestic production 
was insensitive to variation in the price of imported British cloth (incorporating the effects of the tariff), which they interpreted as evidence that the two products were sufficiently differentiated that they did not compete directly. The difficulty with this interpretation is that given the apparent redundancy of the rates that prevailed from the early 1830 s through 1846 there is no reason to expect that marginal variations in tariff rates would have any impact on the volume of domestic production. Although this objection does not apply to the post-1846 period, there was no variation in tariff rates after this date, and British export prices changed little in this period, so it is hardly surprising and not terribly informative that their regression fails to find a relationship between import price movements and domestic cloth production. That American production did not fall after 1846, does suggests that American producers could by this date hold their own against international competition with a minimum of protection. But dating the transition more precisely is nearly impossible given the types of evidence available.

Regardless of how early the Boston Manufacturing Company could have survived in the absence of tariff protection, the disproportionate protection that the minimum valuation clause provided for the coarse machine-made cloth that it produced undoubtedly accelerated the American industry's transition to vertical integration and power weaving based on the Waltham model. This in turn created a pronounced divergence between the British and American industries that is clearly apparent by the 1830s. Fabrics differ in a variety of dimensions, the most important of which are the count —or fineness of the yarn — and the complexity of the weave. While complexity cannot be measured, data allow us to get a sense of the count produced in each country. 
As Peter Temin has documented, by the early 1830s American and British manufacturers were producing almost entirely different products. ${ }^{57}$ An 1833 survey of Lancashire firms, for example, found that counts varied from 8 to 180 , with the average being around 51 . In contrast, the Massachusetts textile firms concentrated in coarser fabrics with counts in the low 20s. In New York, the only state for which a distribution of counts is available $80 \%$ of the cloth produced had counts of under 21 (in comparison just $9 \%$ of Lancashire fabric in 1833 was below 21). Indirect evidence for other states based on the average weight per yard suggests an average count in most states of around 20. Only Pennsylvania appears to have diverged from this pattern.

Associated with these different products were very different technological paradigms. British technological innovation focused on increasing the versatility of machinery to allow shifts in count and fineness in response to shifting market opportunities. Thus considerable effort was devoted to developing a fully automated mule, perfecting looms that could be adapted to producing different weaves of cloth, and roving machines that could produce a wide range of rovings. In contrast, American innovations focused primarily on reducing capital and labor costs by increasing the speed with which standard counts of yarn and standardized fabrics could be produced. By midcentury American advances in continuous spinning had proceeded far enough that they began to be re-imported by British textile machine makers.

\section{Conclusion}

By the mid-nineteenth century, America had emerged as the second largest producer of textiles in the world, and while American manufacturers were not 
competitive in export markets with British manufacturers, they dominated their own large domestic market and had developed a distinctive and eventually highly influential mass production technology that was substantially different from the more vertically disintegrated and craft-based production system in Britain. At the beginning of the eighteenth century, this situation would have been viewed as highly improbable. Explaining how the American textile industry overcame its initial disadvantages is central to our understanding of the larger course of American economic development.

It has been my contention that the development of the American textile industry hinged on a series of historical "accidents." The growth of the American industry was initiated in 1808 by the high level of protection afforded in the years between 1808 and 1815 by the Embargo and Non-intercourse Acts, and the War of 1812. With the return of peace in 1815 , the situation could easily have reverted to something close to the pre-war status quo. Cheap imported cloth flooded domestic markets and caused many manufacturers to abandon production. But the substantial investments made in manufacturing plant, and the large number of manufacturers shifted the political debate and led to the passage of tariff laws that provided protection to at least one branch of the domestic industry, that based on factory production of cloth. This protection, in turn, provided the inducements necessary to develop and perfect this technology.

Tariff protection was, of course, inefficient in terms of static resource allocation. Had tariff rates been set at a lower level in 1816, American consumers would have been able to purchase more cotton cloth at lower prices. But this static inefficiency was important in encouraging dynamic gains in efficiency through technological innovations pursued by American producers. The essence of the infant industry argument is that the 
long-run gains from these advances outweighed the initial costs of the tariff. How one judges the trade-off between costs and benefits hinges on the question of how quickly American producers became able to compete in world markets without tariff protection. Beyond the effects of tariff protection in creating the circumstances in which American textile producers could develop and perfect their own distinctive technology there are other, perhaps even more significant spillovers, though their effects are hard to quantify within the framework of efficiency. One of these spillovers operated through the development of the American machine tool industry and the development of an indigenous community of engineers. Along with small arms producers, textile machine shops were the major source of skilled mechanics who contributed to the emergence of a distinctive American machine building industry in the nineteenth century. A second set of spillovers operated through labor markets. During the 1840s New England textile mills emerged as important magnets for Irish immigrants. In their absence, Irish immigration to the United States might have been slower, with important implications for sectional politics in the 1840 s and 1850 s. Constructing a full blown counterfactual account of American economic development in the absence of the tariff is beyond the scope of this essay, but Australia — a rich, growing economy, reliant primarily on agricultural production and dependent on trade to meet its needs for manufactured goods - offers a vision of one potential alternative path. 


\section{Notes}

${ }^{1}$ D.A. Farnie, The English Cotton Industry and the World Market, 1815-1896 (Oxford: Clarendon Press, 1979), 180. With from 27 to 30 percent of world textile capacity throughout the second half of the nineteenth century the United States industry was far larger than that of any country other than Britain.

${ }^{2}$ David J. Jeremy, Transatlantic Industrial Revolution: The Diffusion of Textile Technologies Between Britain and America, 1790-1830s (Cambridge, MA: MIT Press), ch. 13 describes the return flow of innovations from America to Britain. See also Gary Saxonhouse and Gavin Wright, “Technological Evolution in Cotton Spinning, 1878$1933, "$ in this volume

${ }^{3}$ Jeremy, Transatlantic, 9-13.

${ }^{4}$ John S. Heckman, “The Product Cycle and New England Textiles," Quarterly Journal of Economics 94 (June 1980), 701-3.

${ }^{5}$ Albert Bolles, Industrial History of the United States (Norwich, CT: H. Bill, 1879), pp. 411-12.

${ }^{6}$ This point has been elaborated by a number of authors in slightly different ways. See, in particular Alexander James Field, "Sectoral Shift in Antebellum Massachusetts: A Reconsideration," Explorations in Economic History 15 (1978), 146-171; Gavin Wright, “Cheap Labor and Southern Textiles before 1880," Journal of Economic History 39, no. 3 (September 1979), 655-80; and Claudia Goldin and Kenneth Sokoloff, "Women, Children and Industrialization in the Early Republic: Evidence from the Manufacturing Censuses," Journal of Economic History 42, no. 3 (September 1982), 741-74. 
${ }^{7}$ As I describe below, New England's labor supply advantage was more potential than actual at the outset, and it took the very conscious actions of Francis Lowell and the Boston Manufacturing Company to realize this potential.

${ }^{8}$ Among the best historical descriptions are Caroline F. Ware, The Early New England Cotton Manufacture:A Study in Industrial Beginnings (Boston and New York: Houghton Mifflin, 1931), Robert Brooke Zevin, The Growth of Manufacturing in Early Nineteenth Century New England (New York: Arno Press, 1975); Lance E. Davis and H. Louis Stettler III, “The New England Textile Industry, 1825-60: Trends and Fluctuations,” in Output, Employment and Productivity in the United States After 1800, Dorothy S. Brady, Ed. Conference on Studies in Income and Wealth, Volume 30 (New York: National Bureau of Economic Research, 1966), 213-33; Robert McGouldrick, New England Textiles in the Nineteenth Century: Profits and Investment (Cambridge: Harvard University Press, 1968); and Peter Temin, "Product Quality and Vertical Integration in the Early Textile Industry," Journal of Economic History 48, no. 4 (December 1988), 891-907. Jeremy, Transatlantic, offers the best account of the evolution of technology in the American industry.

${ }^{9}$ On the definition of path-dependence see Paul A. David, "Clio and the Economics of QWERTY: the Necessity of History," in William N. Parker, ed., Economic History and the Modern Economist (Oxford: Blackwell, 1986), 30-49. There has been considerable debate among economists and economic historians about whether path-dependence is more than an intellectual curiosity. S. J. Liebowitz and Stephen E. Margolis, "The Fable of the Keys," Journal of Law and Economics 33 (April 1990), 1-25, have questioned Paul 
David's reading of the evidence regarding the development of typewriter keyboards, and advanced a variety of a priori arguments to support the view that cases of path dependence are extremely unlikely to occur. Both sides of this argument have been discussed at some length on the Eh.Res internet discussion list (see the archive of these discussions at $<$ http://www.eh.net/FORUMS/PathDepe.html $>$ and http://www.eh.net/FORUMS/QWERTYSu2.html). The force of many of the theoretical arguments made by Liebowitz and Margolis is blunted, however, when, as is the case here, political forces interact with economic ones.

${ }^{10}$ Major contributions to this literature begin with F. W. Taussig, The Tariff History of the United States (New York and London: G. P. Putnam's Sons, 1931), who argued that tariff protection was unnecessary by the early 1830s. Mark Bils, "Tariff Protection and Production in the Early U.S. Cotton Textile Industry," Journal of Economic History 44, no. 4 (December 1984), and C. Knick Harley, "International Competitiveness of the Antebellum American Cotton Textile Industry," Journal of Economic History 52, no. 3 (September 1992), 559-84 argued to the contrary that protection was important for much longer. Recently Douglas A. Irwin and Peter Temin, "The Antebellum Tariff on Cotton Textiles Revisited," Journal of Economic History 61, no. 3 (September 2001), 777-798. have attempted to revive the view that the American industry quickly attained international competitiveness. C. Knick Harley, "The Antebellum Tariff: Different Products or Competing Sources? A Comment on Irwin and Temin," Journal of Economic History 61, no. 3 (September 2001), 799-805, offers a rebuttal.

${ }^{11}$ Jeremy, Transatlantic, 80-83. 
12 Jeremy, Transatlantic, 17-18; Ware, Early New England, 20.

${ }^{13}$ The first spinning mill in the U.S. based on the Arkwright technology employed a labor force consisting of 9 children between the ages of 4 and 10, and a single adult supervisor. Ware, Early New England, 21-22.

${ }^{14}$ Jeremy, Transatlantic, 76-77.

${ }^{15}$ Ware, Early New England, 19-20.

16 Jeremy, Transatlantic, 83.

17 “Antebellum Tariff," 794.

${ }^{18}$ Jeremy, Transatlantic, 90, concludes based on the high proportion of women and children reported in the textile labor force in the 1810 census that the bulk of the 31,000 spindles recorded in that year must have relied on the Arkwright technology, rather than mules, which required comparatively more adult male operatives

${ }^{19}$ See Mary Freifeld, "Technological Change and the 'Self-Acting Mule: A Study of Skill and the Sexual Division of Labour," Social History 11, no. 3 (October 1986), 323-28.

${ }^{20}$ Jeremy, Transatlantic, 56-58.

${ }^{21}$ Ware, Early New England, 39-42.

${ }^{22}$ Ware, Early New England, 41-45, 48.

${ }^{23}$ Annals of Congress of the United States, Fourteenth Congress, First Session (Washington: Gales and Seaton, 1854), 962-63.

${ }^{24}$ Ware, Early New England, 50-53.

${ }^{25}$ It is perhaps worth recalling that one impetus to the initial British innovations in spinning was the scarcity of yarn confronting hand weavers in mid-eighteenth century 
Britain. Neil Smelser, Social Change in the Industrial Revolution (London: Routledge \& Kegan Paul, 1959), ch. 4.

${ }^{26}$ On Lowell's time in Scotland and speculations about his motivations for entering into textiles production see Robert F. Dalzell, Enterprising Elite: The Boston Associates and the World They Made (Cambridge: Harvard University Press, 1987), 5-25.

${ }^{27}$ Nathan Appleton, The Power Loom and the Origin of Lowell (Lowell: B. H. Penhallow, 1858), 11-12.

${ }^{28}$ Gary R. Saxonhouse and Gavin Wright, "New Evidence on the Stubborn English Mule and the Cotton Industry, 1878-1920," Economic History Review 37, no. 4 (November 1984), 514-15, link the choice between mules and rings in different countries largely to the quality of local cotton supplies. Ring spinning would work only with long-staple cottons, while mules were capable of spinning a greater variety of cotton.

${ }^{29}$ Hannah Josephson, The Golden Threads: New England's Mill Girls and Magnates (New York: Duell, Sloan and Pierce, 1949), 22-24. In effect the company's involvement in providing housing for its workers represented another stage of vertical integration, extending the company's operations into the management of the supply of labor inputs. Similarly, the company's reliance on its own machine shop to produce and maintain its equipment was another manifestation of this vertical integration.

${ }^{30}$ Because of cultural conventions and agricultural technology, there was a substantial pool of surplus labor on New England farms in the early nineteenth century. The opening of the Erie Canal and the effects of competition from Midwestern farms further increased this supply in the 1820 s as textile labor demand expanded rapidly. Field, "Sectoral 
Shift," and Goldin and Sokoloff, "Women." But in 1815 this surplus labor was just a potential source of labor. It took the institutional innovations introduced by the Boston Manufacturing Company to realize this potential.

31 Jeremy, Transatlantic, 56, 101.

${ }^{32}$ Freifeld, “Technological Change,” 337-8.

${ }^{33}$ Zevin, Growth, 37; Jeremy, Transatlantic, 181.

${ }^{34}$ Estimates of total factor productivity growth in this period suggest that it was increasing at a rate of between 6 and 7 percent per year. Paul A. David, Technical Choice, Innovation, and Economic Growth: Essays on American and British Experience in the Nineteenth Century (Cambridge: Cambridge University Press, 1975), ch.2; and Zevin, Growth.

35 Jeremy, Transatlantic, ch. 10.

${ }^{36}$ Ware, Early New England, 73-75.

${ }^{37}$ See Philip Scranton, Proprietary Capitalism: The Textile Manufacture of Philadelphia, 1800-1885 (Cambridge: Cambridge University Press, 1983)

38 Temin, "Product," 895.

${ }^{39}$ Edward Stanwood, American Tariff Controversies in the Nineteenth Century (2 vols., Westminster: Archibald Constable, 1904), 131.

${ }^{40}$ Irwin and Temin, “Antebellum Tariff” 794.

${ }^{41}$ Appleton, Power Loom, 13.

${ }^{42}$ Annals of Congress, 966.

${ }^{43}$ Stanwood, American, 146; Josephson, Golden Threads, 29-31. 
${ }^{44}$ Because the duty was not applied to the shipping costs, the effect on prices in American markets was more muted, but it is in comparison with the production costs that the tariff's impact should be assessed. In the absence of the minimum clause, the effective tariff would have been substantially smaller.

${ }^{45}$ Appleton, Power Loom, 13.

${ }^{46}$ Irwin and Temin, “Antebellum Tariff,” 779; Josephson, Golden Threads, 30-31.

${ }^{47}$ Quoted in Kenneth Wiggins Porter, The Jacksons and the Lees: Two Generations of Massachusetts Merchants, 1765-1844 (2 vols., Cambridge: Harvard University Press, 1937), 40 .

${ }^{48}$ Irwin and Temin, “Tariff,” 794.

${ }^{49}$ Ware, Early New England, 66-67.

${ }^{50}$ Scranton, Proprietary Capitalism, 76-83, 96-99.

${ }^{51}$ Ware, Early New England, 70.

${ }^{52}$ Zevin, "Growth", 10:9-10, argued that import substitution can account for only a small fraction of the expansion of domestic production after 1816, a view that would appear to discount the importance of tariff protection. But in fact, Zevin's views are not at odds with the interpretation offered here. As Zevin goes on to observe "In the market for plain cloths which New England mills supplied in significant quantities, New England already supplied nearly 100 per cent of market requirements in 1816.” Logically, then, import substitution relative to this initial position cannot have been important. But had tariffs been lower, much of the growth in demand supplied by the domestic industry might instead have been supplied by imports. It is to this counterfactual situation that we must 
compare the actual outcome to assess the extent to which import substitution was important in stimulating the domestic industry's growth.

53 “Antebellum Tariff," 780-81.

${ }^{54}$ Tariff History, 33-35.

${ }^{55}$ Bils, "Tariff"; and Harley, "International Competiveness."

56 "Antebellum Tariff."

57 “Product Quality," 894-96. 
Table 1

Cotton Textile Capacity in The United States and Britain, 1790-1895

\begin{tabular}{lccc}
\hline & \multicolumn{2}{c}{ Thousands of Spindles } & Ratio \\
Date & United States & Great Britain & (U.S./Great Britain) \\
1790 & 2 & 2,410 & 0.001 \\
1805 & 5 & & \\
1809 & 8 & 5,850 & \\
1812 & 93 & 7,850 & 0.016 \\
1817 & 333 & 9,000 & 0.042 \\
1832 & 2,800 & 17,500 & 0.311 \\
1845 & 7,500 & 21,000 & 0.429 \\
1850 & 9,600 & 30,300 & 0.457 \\
1861 & 10,000 & 37,500 & 0.330 \\
1875 & 19,500 & 39,750 & 0.520 \\
1880 & 20,805 & 43,000 & 0.523 \\
1885 & 22,750 & 43,750 & 0.529 \\
1890 & 25,460 & 45,400 & 0.582 \\
1895 & 28,200 & & 0.621 \\
\hline
\end{tabular}

Sources: David J. Jeremy, Transatlantic Industrial Revolution: The Diffusion of Textile Technologies Between Britain and America, 1790-1830s (Cambridge: MIT Press, 1981), 91; F. W. Taussig, The Tariff History of the United States (New York and London: G. P. Putnam's Sons, 1931), 28; D. A. Farnie, The English Cotton Industry and the World Market, 1815-1896 (Oxford: Clarendon Press, 1979), 180. 
Table 2:

Voting on Selected Amendments to the Tariff Bill of 1816

\begin{tabular}{|c|c|c|c|c|}
\hline \multirow[b]{2}{*}{ State and Region } & \multicolumn{2}{|c|}{$\begin{array}{l}\text { To Reduce Tariff on Cotton Textiles from } \\
30 \text { percent to } 25 \text { percent in first } 2 \text { years }\end{array}$} & \multicolumn{2}{|c|}{$\begin{array}{l}\text { To Eliminate the Minimum } \\
\text { Clause }\end{array}$} \\
\hline & Against & For & Against & For \\
\hline New England & 12 & 21 & 18 & 9 \\
\hline Connecticut & 2 & 4 & 2 & 3 \\
\hline Massachusetts & 6 & 7 & 8 & 1 \\
\hline New Hampshire & 0 & 6 & 2 & 3 \\
\hline Rhode Island & 2 & 0 & 2 & 0 \\
\hline Vermont & 2 & 4 & 4 & 2 \\
\hline Mid Atlantic & 34 & 9 & 43 & 4 \\
\hline New Jersey & 4 & 0 & 5 & 0 \\
\hline New York & 16 & 4 & 21 & 1 \\
\hline Pennsylvania & 14 & 5 & 17 & 3 \\
\hline Midwest & 3 & 0 & 3 & 0 \\
\hline Ohio & 3 & 0 & 3 & 0 \\
\hline South & 11 & 53 & 18 & 42 \\
\hline Delaware & 0 & 1 & 0 & 0 \\
\hline Maryland & 0 & 8 & 2 & 4 \\
\hline Virginia & 2 & 17 & 4 & 14 \\
\hline North Carolina & 0 & 9 & 0 & 11 \\
\hline South Carolina & 2 & 7 & 6 & 3 \\
\hline Georgia & 0 & 6 & 0 & 5 \\
\hline Kentucky & 5 & 2 & 6 & 2 \\
\hline Tennessee & 2 & 2 & 0 & 2 \\
\hline Louisiana & 0 & 0 & 0 & 1 \\
\hline Mississippi & 0 & 1 & 0 & 0 \\
\hline Total & 60 & 83 & 82 & 60 \\
\hline
\end{tabular}

Source: Annals of Congress of the United States, Fourteenth Congress, First Session (Washington: Gales and Seaton, 1854), 1314, 1348-49. These counts are based on the information on roll call votes on these issues. The totals do not always accord with the summary figures reported in the source. The reason for the discrepancy is not known. 
Table 3:

Textile Employment in Philadelphia, 1814-1820

\begin{tabular}{lrrrrr}
\hline Date & Cotton & \multicolumn{2}{c}{ Thread } \\
(spinning yarn) & Wool & Other $^{\mathrm{a}}$ & Total \\
\hline \multicolumn{7}{c}{ Number } \\
1814 & 1,761 & 444 & 1,310 & 146 & 3,661 \\
1816 & 2,325 & 191 & 1,226 & 78 & 3,820 \\
1820 & 149 & 20 & 260 & 54 & 483 \\
& 671 & 92 & 334 & 42 & 1,139 \\
1814 & 100.00 & 100.00 & 100.00 & 100.00 & 100.00 \\
1816 & 132.03 & 43.02 & 93.59 & 53.42 & 104.34 \\
1819 & 8.46 & 4.50 & 19.85 & 36.99 & 13.19 \\
1820 & 38.10 & 20.72 & 25.50 & 28.77 & 31.11 \\
\hline
\end{tabular}

Source: Philip Scranton, Proprietary Capitalism: The Textile Manufacture at Philadelphia, 1800-1885 (Cambridge: Cambridge University Press, 1983), 121.

a This category comprises employment in hosiery, floor cloth (carpets) and other textile employment. 


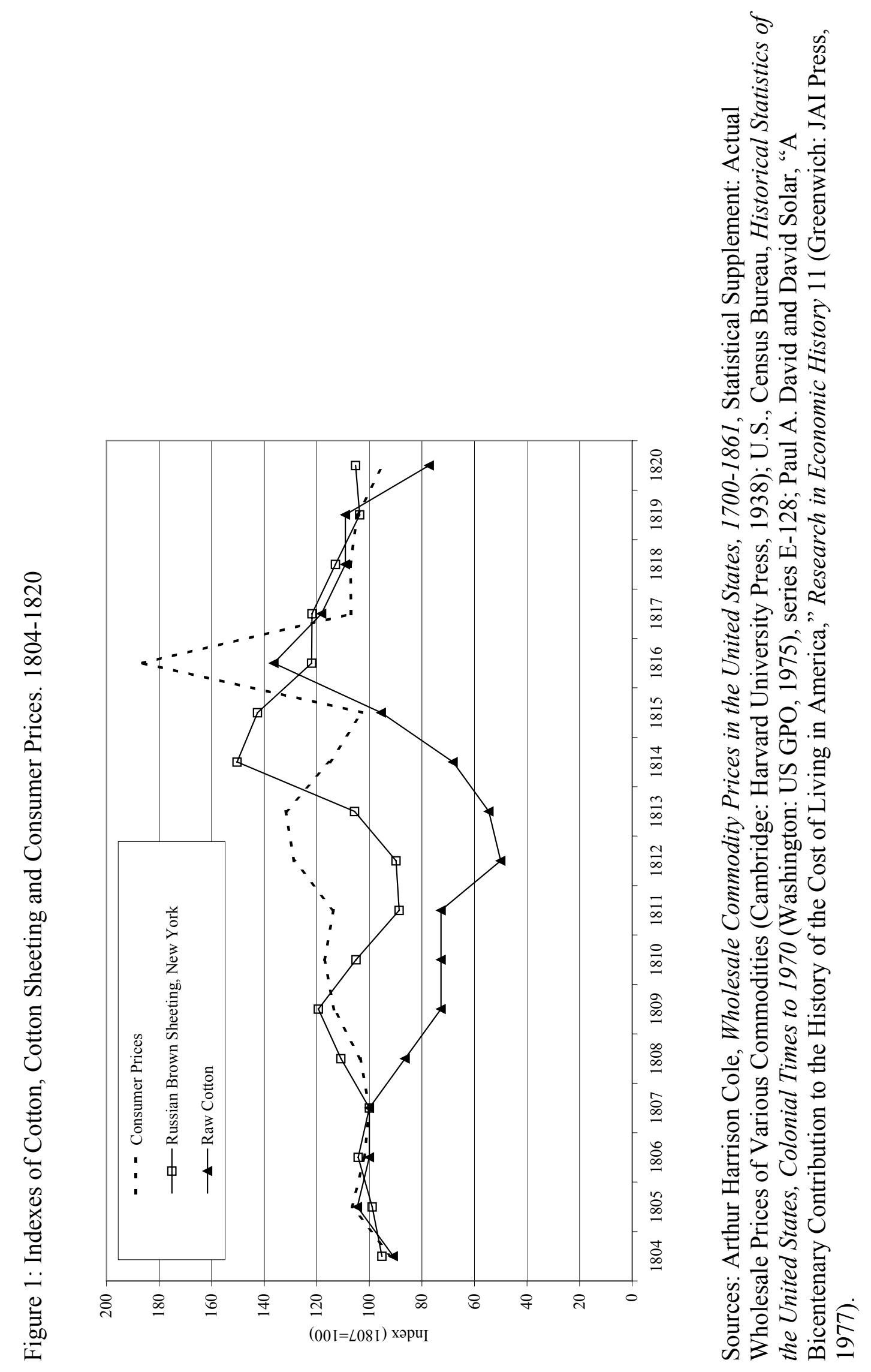




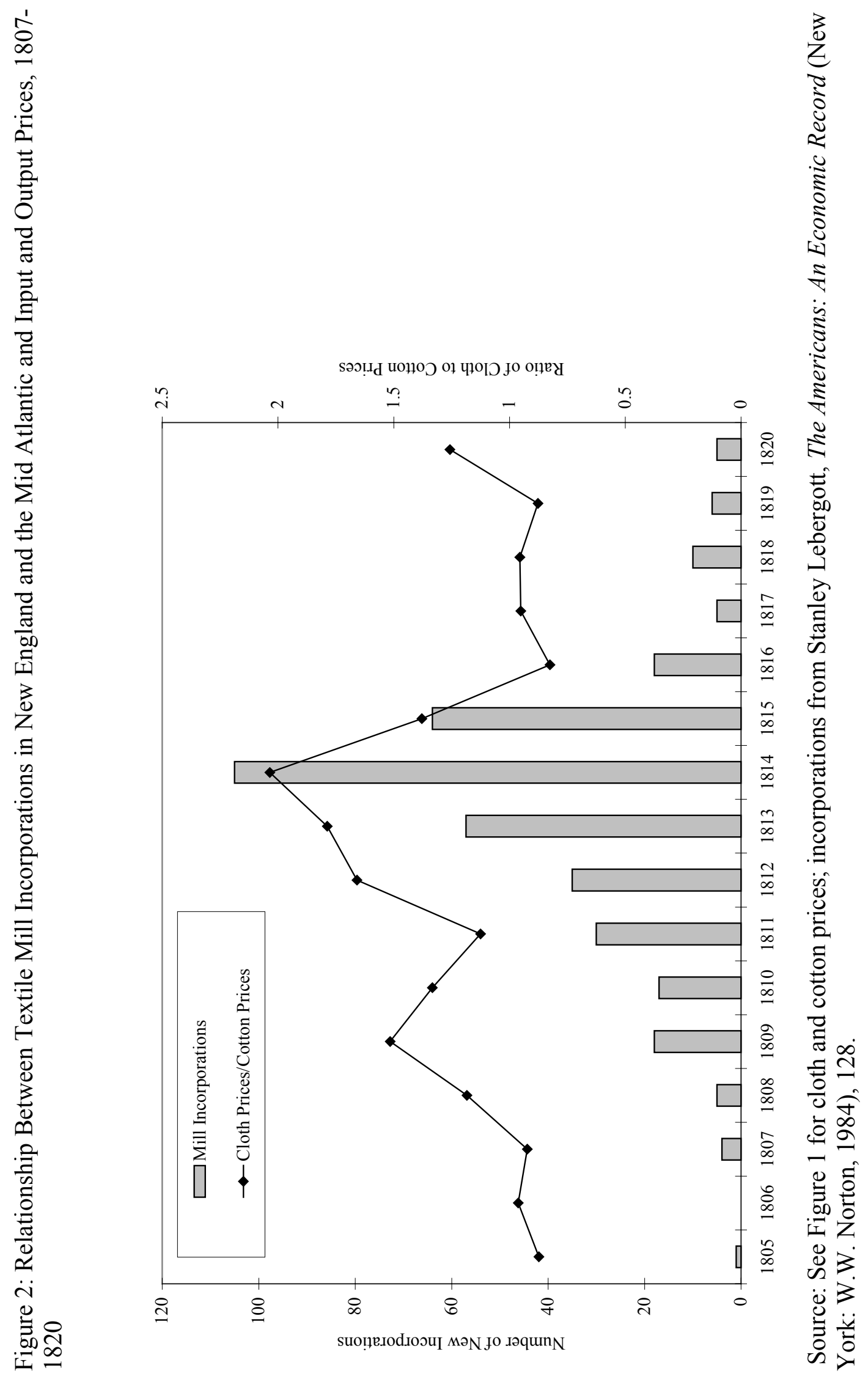




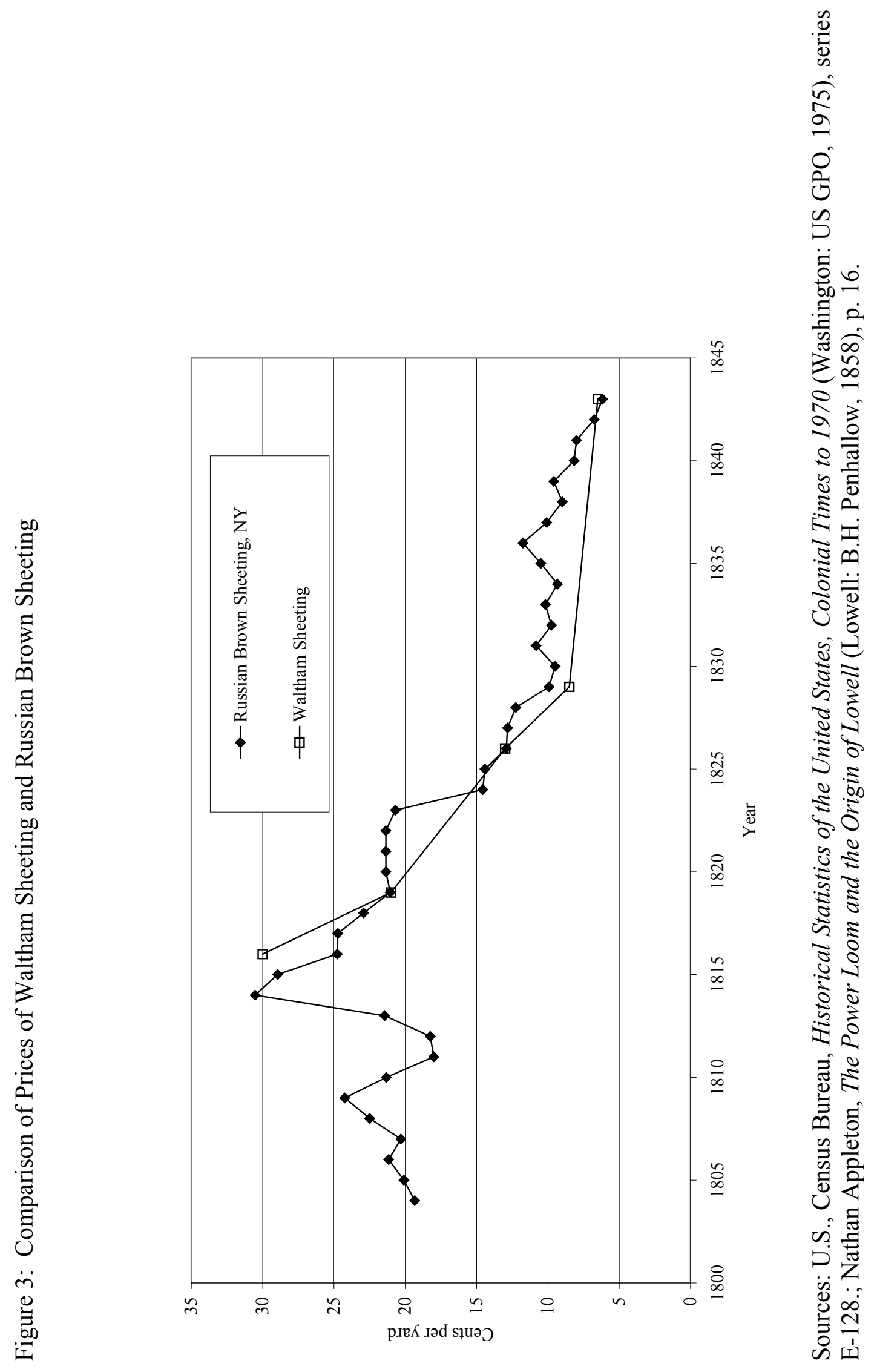

